\title{
Immunological manipulation of ovulation rate for twinning in cattle
}

\author{
M. A. Hillard ${ }^{1}$, J. F. Wilkins ${ }^{2}$, L. J. Cummins ${ }^{3}$, B. M. Bindon ${ }^{1}$, \\ C. G. Tsonis ${ }^{4}$, J. K. Findlay ${ }^{5}$ and T. O'Shea ${ }^{6}$ \\ ${ }^{1}$ CSIRO, Division of Animal Production, Private Mail Bag, Armidale NSW 2350, Australia; \\ ${ }^{2}$ NSW Agriculture, Agricultural and Research Advisory Station, PMB, Grafton, NSW 2460, \\ Australia; ${ }^{3}$ Department of Agriculture, Pastoral and Veterinary Institute, Private Bag, Hamilton \\ VIC 3300, Australia; ${ }^{4}$ Biotech Australia Pty Ltd, PO Box 20, East Roseville, NSW 2069, \\ Australia; ${ }^{5}$ Prince Henry's Institute of Medical Research, Clayton, VIC 3168, Australia; and \\ ${ }^{6}$ Deparlment of Physiology, University of New England. Armidale NSW 2351. Australia
}

Unlike in sheep, in which immunization against androstenedione causes mild and reasonably controlled increased ovulation rate, in similar studies cattle showed highly variable responses ranging from increased ovulation rate and fertility through to anovulation/anoestrus or superovulation. As a consequence, interest in manipulation of ovulation rate through this approach has declined and is now focused on immunological manipulation of endogenous inhibin following successful studies in sheep. Studies have concentrated on developing a prototype inhibinbased vaccine to be used for twinning in the Australian beef industry. The prototype vaccine (with recombinant ovine inhibin- $\alpha .3$ fusion protein and Montanide:Marcol adjuvant) has proved to be very potent and control of the degree of ovarian stimulation has not been possible. The proportion of cattle with increased ovulation rate after inhibin immunization is affected by timing of booster vaccination within the ovarian cycle, time after vaccination, vaccine formulation and possibly genotype. Physiological studies show that cattle responding to the inhibin vaccine have increased plasma inhibin binding of native bovine inhibin, high plasma FSH concentrations, greater numbers of large $(\geq 8 \mathrm{~mm})$ follicles and fewer small $(<5 \mathrm{~mm})$ follicles during the preovulatory wave of follicular development compared with control or non-responding animals. Significant correlations among the response parameters (i.e. inhibin binding, plasma FSH concentrations, number of large follicles and ovulation rate) have been demonstrated. The results indicate that greater understanding of the various processes of folliculogenesis will be necessary to achieve a controlled increase in ovulation rate in cattle.

\section{Introduction}

Interest in the use of immunological techniques to manipulate reproductive efficiency in domestic ruminants has increased since the report by Scaramuzzi ef al. (1977) that androstenedione-immunized Welsh Mountain ewes exhibit high ovulation rates with normal ovarian cycles. This discovery led to the release, some years later, of a commercial product (Fecundin) designed to increase prolificacy in sheep. Studies in cattle directed at immunomodulation of ovarian function have followed these studies in ewes.

In this review, immunological manipulations of ovarian hormones (principally androgenic steroids and inhibin) that have resulted in increased ovulation rate, the major factor limiting fecundity in cattle, will be discussed and the results from some more recent studies with recombinant inhibin vaccines will 
be presented. Suppression of ovarian function will not be considered as recent reviews (see Hoskinson et al, 1990; D'Occhio, 1993) have covered this area of research.

When compared with sheep, attempts to increase ovulation rate in cattle by active immunization against steroid hormones have been less successful. Wise and Schanbacher (1983) reported twin ovulations in four of 15 androstenedione-immunized Simmental cross-heifers, three of which had twin fetuses at about day 47 of pregnancy. Similar studies using either beef or dairy cattle (Sreenan, 1984; Walton, 1985; Hoskinson et al., 1986) failed to repeat this response and indicated various degrees of ovarian dysfunction (superovulation, cystic follicles, anovulation/anoestrus).

Immunization of Charolais $\times$ Simmental heifers against testosterone either stimulated ovulation rate or resulted in anoestrus lasting up to 11 months (Price et al., 1987a). As in sheep (Scaramuzzi and Hoskinson, 1984), ovulation rates in testosterone-immune cows are increased with either equine chorionic gonadotrophin (Boland et al., 1985) or human chorionic gonadotrophin (Hoskinson et al., 1986). The latter ovulatory response was associated with reduced expression of oestrous behaviour (Hoskinson et al., 1986).

The divergent ovulatory responses observed in androgen-immune cattle are possibly related to relatively small changes in antibody titre (Hoskinson ef al., 1986). On the basis of these responses, and given the history of Fecundin (see Scaramuzzi and Hoskinson, 1984; Smith, 1985; Philipon and Driancourt, 1987; Croker et al., 1988), it is unlikely that development of a similar product for increasing cattle prolificacy will be achieved without much more intensive research.

\section{Immunization Against Inhibins}

\section{Nafive inhibin immunogens}

O'Shea et al. (1982) reported increased ovulation rate in sheep immunized with a crude bovine follicular fluid 'inhibin' extract in Freund's complete adjuvant (FCA). This was confirmed by Henderson et al. (1984) and O'Shea et al. (1984) and the resultant increase in prolificacy of inhibin immune ewes demonstrated. Immunization of cows against a similar preparation of native ovine inhibin (Cummins et al., 1986) resulted in multiple $(2-6)$ ovulations in six of 12 treated animals. Price et al. (1987b) then described transient increases of one or two ovulations in yearling Charolais $\times$ Simmental heifers treated with similarly prepared ovine follicular fluid inhibin.

Vaccination of pubertal beef heifers with an immunoaffinity-purified preparation of ovine follicular fluid inhibin resulted in more consistent and significant multi-ovulatory responses after booster vaccinations (Bindon et al, 1988; O'Shea et al, 1994). Preliminary studies (Hillard $e$ t al., 1990; Bindon et al., 1994) showed that ovulation rates of Hereford cows immunized against a similar preparation were high and more transferable embryos were produced after mild treatment with exogenous ovine FSH than in control animals.

\section{Synthetic inhibin a-chain fragments}

Immunization of cattle with synthetic inhibin $\alpha$-chain fragments (conjugated to appropriate carrier proteins for increased immunogenicity) produced variable effects on ovulation rate. In early investigations using porcine $\alpha_{1-32}$ fragment in FCA, three of eight treated cows showed increased ovulation rate ( 2 or 3 ) after the first booster vaccination (B. Bindon, M. Hillard and T. O'Shea, unpublished). Despite some evidence to the contrary (Scanlon et al, 1993; Rhind et al., 1993), similar significant increases in ovulation rate have been observed in beef and dairy heifers subjected to multiple (2-8) booster vaccinations with different bovine inhibin $\alpha$-chain fragments (Glencross et al., 1992; Morris et al., 1993; Scanlon ef al, 1993) when potent adjuvant mixtures were used in the primary injection. Morris et al. (1993) showed that the significantly higher ovulation rate observed after each booster immunization declined with time after immunization. They also showed that twin calving rate was significantly increased in inhibin-immune heifers.

Early screening studies, to identify a suitable inhibin immunogen to be used in a Montanide:Marcol based (Forage et al., 1987) vaccine for cattle twinning, failed to demonstrate any ovulation rate effects in post-pubertal beef heifers after two booster vaccinations with synthetic fragments $\left(\alpha_{1-27}\right)$ from human, 
Table 1. Ovulation rates, number of animals with two or more ovulation rate records of greater than 1 (ovulation rate $>1$ ) and inhibin binding in heifers after two booster vaccinations with native or synthetic peptides, or recombinant inhibin formulations with Montanide:Marcol

\begin{tabular}{|c|c|c|c|c|c|c|}
\hline Treatment (immunogen) & $\begin{array}{l}\text { Dose } \\
(\mu g)\end{array}$ & $n$ & $\begin{array}{l}\text { Number of } \\
\text { ovulatory } \\
\text { cycles }\end{array}$ & $\begin{array}{c}\text { Ovulation rate } \\
\text { (mean } \pm \text { SEM) }\end{array}$ & $\begin{array}{c}\text { Heifers with } \\
\text { two ovulation } \\
\text { rate }>1\end{array}$ & $\begin{array}{l}\text { Inhibin } \\
\text { binding } \\
\text { (\%) }\end{array}$ \\
\hline Control & - & 23 & 54 & I & 0 & 0 \\
\hline Bovine- $\alpha_{1-27}$ inhibin & 200 & 8 & 16 & 1 & 0 & 0 \\
\hline Human- $a_{1-27}$ inhibin & 200 & 8 & 16 & $1.1 \pm 0.10$ & 0 & $16 \pm 2$ \\
\hline Porcine- $\alpha_{1-27}$ inhibin & 200 & 8 & 16 & 1 & 0 & 0 \\
\hline Recombinant bovine- $\alpha .1$ inhibin & 500 & 8 & 16 & $1.1 \pm 0.1$ & 0 & $33 \pm 3$ \\
\hline Recombinant human- $\alpha .2$ inhibin & 500 & 8 & 24 & $1.7 \pm 0.3$ & 1 & $13 \pm 2$ \\
\hline Recombinant ovine- $\alpha .2$ inhibin & 500 & 8 & 15 & $1.7 \pm 0.3$ & 2 & $22 \pm 3$ \\
\hline Recombinant ovine- $\alpha .2$ inhibin & 1000 & 8 & 15 & 1 & 0 & $20 \pm 2$ \\
\hline Recombinant ovine- $\alpha .2$ inhibin & 2500 & 8 & 15 & $1,2 \pm 0.4$ & 0 & $25 \pm 3$ \\
\hline Recombinant ovine- $\alpha .3$ inhibin & 500 & 7 & 19 & $3.4 \pm 0.8$ & 5 & $21 \pm 5$ \\
\hline Recombinant ovine- $\alpha .3$ inhibin & 1000 & 8 & 15 & $2.6 \pm 0.1$ & 2 & $25 \pm 3$ \\
\hline Recombinant ovine- $\alpha .3$ inhibin & 2500 & 8 & 15 & $1.6 \pm 0.3$ & I & $26 \pm 3$ \\
\hline Recombinant human inhibin & $33 \cdot 3$ & 8 & 15 & 1 & 0 & 0 \\
\hline Recombinant human inhibin & 100 & 8 & 21 & $2.4 \pm 0.5$ & 2 & $15 \pm 4$ \\
\hline Recombinant human inhibin & 300 & 8 & 16 & $2.4 \pm 0.6$ & 3 & $16 \pm 5$ \\
\hline oMPI & 400 & 8 & 24 & $7.0 \pm 2.7$ & 3 & $5 \pm 3$ \\
\hline
\end{tabular}

$n=$ number of animals.

Inhibin binding refers to percentage ${ }^{125}$ I-labelled $31 \mathrm{kDa}$ bovine inhibin-A bound by $0.6 \mathrm{ml}$ plasma diluted $1: 3$.

oMPl: ovine monoclonal purified inhibin preparation.

bovine or porcine inhibin $\alpha$-subunits. Specific binding of ${ }^{125}$ I-labelled bovine inhibin was demonstrated only in plasma obtained from heifers treated with the human- $\alpha_{1-27}$ peptide (see Table 1).

\section{Recombinant inhibin and inhibin- $\alpha$ subunits}

Recombinant human inhibin and four inhibin- $\alpha$. fusion proteins (and monoclonally purified ovine follicular fluid inhibin) were also included in the immunoneutralization screening studies to select an immunogen for use as a prototype cattle twinning vaccine. The results (Table 1) show that recombinant inhibin immunogens produced various effects on ovulation rate and inhibin binding. Despite producing significant inhibin binding, recombinant bovine- $\alpha$ did not increase ovulation rate. Although both the complete molecule of recombinant human inhibin and recombinant ovine- $\alpha .3$ preparations were effective in increasing mean ovulation rates, only the latter immunogen was effective in increasing ovulation rate in a significant proportion of treated heifers after both booster vaccinations. These early screening studies (confounded by time) indicate that immunogen dose may have an effect on both mean ovulation rates and the proportions of animals responding after booster vaccinations with recombinant human (complete molecule) and ovine inhibin- $\alpha .3$ fusion protein.

Native ovine inhibin resulted in low inhibin binding but confirmed the earlier results by demonstrating an increase in mean ovulation rate. Superovulation (i.e. ovulation rate $\geq 8$ ) was also a feature of the increased ovulatory response observed after the second booster vaccination with recombinant human fusion protein.

A dose-response study in heifers (Bindon ef al., 1994, O'Shea et al., 1994) showed no significant differences in ovulation responses of heifers to increasing doses $(125,250,500$ and $1000 \mu \mathrm{g})$ of immunogen in synchronized cycles after booster vaccinations. A formulation with $500 \mu \mathrm{g}$ fusion protein per immunizing dose $(500 \mu \mathrm{g}$ recombinant ovine inhibin- $\alpha .3$ in $0.9 \mathrm{ml} 0.15 \mathrm{~mol}$ sodium phosphate 
Table 2. Effect of timing of booster injection of ovine inhibin- $\alpha .3$ vaccine (days 2,9 or 16 of the ovarian cycle) on subsequent ovulation rates in parous inhibin-immunized cows: (i) pooled data from two trials conducted at Hamilton in 1991 and 1992, and (ii) pooled data from two trials in which cows were booster vaccinated with either prototype inhibin vaccine or placebo (control) at Armidale and Grafton in 1992

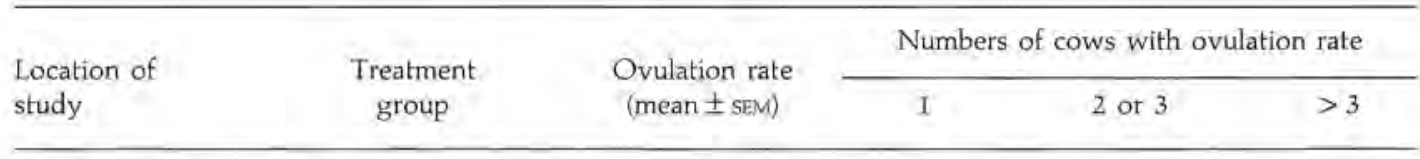

$\begin{array}{ll}\text { (i) Hamilton } & \text { Vaccinated } \\ & \text { Day 2 } \\ & \text { Day 9 } \\ & \text { Day 16 } \\ \text { (ii) Armidale } & \text { Control (day 2) } \\ \text { and Grafton } & \text { Vaccinated (day 2) }\end{array}$

$\begin{array}{cr}2.5 \pm 0.3^{\mathrm{b}} & 5 \\ 4.2 \pm 0.8^{\mathrm{b}} & 5 \\ 1.4 \pm 0.2^{\mathrm{c}} & 16 \\ 1.0^{\mathrm{d}} & 22 \\ 3.3 \pm 0.3^{\mathrm{e}} & 24\end{array}$

$\begin{array}{rrr}5 & 10 & 6 \\ 5 & 9 & 8 \\ 6 & 5 & 0 \\ 2 & 0 & 0 \\ 4 & 25 & 27\end{array}$

Unpublished data of (i) L. Cummins, A. Clark, M. Hannah and E. van Rijswijk (ii) J. Wilkins, M. Hillard, C. Tsonis and J. Findlay. Two immunizations with $500 \mu \mathrm{g}$ recombinant ovine inhibin- $\alpha .3,28$ days apart.

Values in columns with different superscripts are significantly different, $P<0.01^{b}$ and ${ }^{c} ; P<0.001^{d}$ and .

Ovulation rate for control cows $(1.2 \pm 0.1, n=12)$ was significantly different $(P<0.001)$ from that of inhibin-immunized cows treated on day 2 or day 9 in the 1991 trial at Hamilton.

Distribution of ovulation rate significantly different, (i) $P<0.01$; (ii) $P<0.001$.

buffer $\mathrm{l}^{-1}$ containing $0.15 \mathrm{~mol} \mathrm{NaCl} \mathrm{I}^{-1}$ emulsified with $1.1 \mathrm{ml}$ Montanide 888 (SEPPIC, Paris):Marcol 52 (ESSO, Sydney) in the ratio of $1: 9$ as adjuvant injected i.m., see Forage et al, 1987) was chosen for evaluation as a prototype vaccine because there was less variability in the proportion of heifers responding to this dose with increased ovulation rate.

\section{Evaluation of a Prototype Recombinant Inhibin Vaccine for Twinning in Beef Cattle}

During the earlier screening trials of the various inhibin antigens, in which primary and booster vaccinations were administered without regard to the stage of the ovarian cycle, overall repeatability of ovulation rate within animals was low and unrelated to plasma inhibin binding. Initial trials of the effects of the prototype vaccine in cattle addressed this problem. Unless otherwise stated, the ovulation rate was determined by trans-rectal real-time ultrasound imaging of the ovaries 8 to 10 days after the oestrus following booster immunization.

\section{Timing of booster immunization - effects on ovulation rate response}

Two studies, with Hereford and Friesian $\times$ Hereford cows, were conducted at Hamilton (Victoria) in spring (1991) and winter (1992). Primary vaccination with the prototype vaccine of randomly cyclic cows was followed 28 days later by booster immunization on days 2,9 or 16 of a synchronized ovarian cycle. The cows were mated at the following oestrus. Placebo-treated (control) cows were included only in the experiment performed in 1991. ANOVA and deviance analyses (using generalized linear model procedures: McCullagh and Nelder, 1989) of the results from this study, within the I991 trial, showed a significant effect of inhibin vaccination on mean ovulation rate $(P<0.01)$ and significantly higher proportions of cows boosted on days 2 and 9 had ovulation rates $>1(P<0.05)$, while the values for the cows treated on day 16 did not differ from control values. Booster vaccination on day 2 was more effective in inducing multiple-pregnancy in cattle in the trial conducted in 1991 (Bindon et al., 1994).

There were significant effects of treatment day $(P<0.01)$ on ovulation rate distributions within and across trials (Table 2). Analysis of the combined data for the two experiments shows no effect of year or year $x$ treatment interaction. No difference was found between the groups treated on days 2 and 9 in distribution of ovulation rate, but their distributions were significantly different $(P<0.005$ and $P<0.001)$ 
Table 3. Comparison of ovulation rate in unselected heifers and heifers selected for twinning after booster vaccination with prototype recombinant inhibin- $\alpha .3$ (recombinant ovine- $\alpha .3$ ) or placebo (nil antigen) vaccines

\begin{tabular}{|c|c|c|c|c|c|}
\hline Breed & Vaccine & $n$ & $\begin{array}{l}\text { Live mass } \\
(\mathrm{kg})\end{array}$ & $\begin{array}{c}\text { Cows with } \\
\text { ovulation rate }>1\end{array}$ & $\begin{array}{c}\text { Ovulation rate } \\
\text { (mean } \pm \text { SEM) }\end{array}$ \\
\hline \multirow[t]{2}{*}{ Unselected Herefords } & Nil & 8 & $477 \pm 13$ & I & $1.1 \pm 0.1$ \\
\hline & Recombinant ovine- $\alpha .3$ & 8 & $491 \pm 16$ & 2 & $2.6 \pm 1.5$ \\
\hline \multirow[t]{2}{*}{ Twin selection herd ${ }^{b}$} & Nil & 10 & $425 \pm 8$ & 1 & $1.1 \pm 0.1 *$ \\
\hline & Recombinant ovine- $\alpha, 3$ & 10 & $428 \pm 8$ & $9^{* *}$ & $3.1 \pm 0.7^{*}$ \\
\hline
\end{tabular}

Unpublished data of $\mathrm{M}$. Hillard and $\mathrm{B}$. Bindon.

${ }^{a}$ Ovulation rates assessed 14 days after the first booster immunization with $500 \mu \mathrm{g}$ recombinant ovine- $\alpha .3$ inhibin. ${ }^{6}$ See Piper and Bindon (1990) for details.

*Significantly different $(P<0.05)$.

**Significantly different from all other treatment groups $\left(P<0,05-<0.001: \chi^{2}\right)$.

from that observed in the day 16 group. A small experiment at Grafton in 1991 also indicated that giving a booster on day 2 gave a less variable and mild increase in ovulation rate than giving a booster on day 9.

Two field tests of the prototype vaccine, with booster injection given on day 2 of a synchronized cycle, were conducted in 1992 (Table 2). The cows were either mated with bulls over two cycles (Grafton), or artificially inseminated at the first synchronized cycle followed by mating with bulls for the following 70 days (Armidale). Inhibin vaccination resulted in similar increases in mean ovulation rate $(P<0.001$, ANOVA, overall mean $3.34 \pm 0.29$ for vaccinated versus 1.0 for controls $)$, and ovulation rate distribution was significantly different from controls $(P<0.001)$. There were no site or site $x$ treatment interaction effects.

Although early pregnancy data for the cows in these two studies (and the 1991 study at Hamilton) showed that $40-50 \%$ of pregnant cows were carrying multiple fetuses at days $40-45$ of gestation, subsequent fetal mortality (notably in cows with ovulation rates $\geq 3$ ) resulted in highly variable numbers of calves born (Hillard et al, 1994; Wilkins et al., 1994).

\section{Effects of genotype of cattle}

The ovarian response to recombinant ovine inhibin- $\alpha .3$ vaccination was compared in unselected commercial Hereford heifers and heifers from the CSIRO herd selected for twinning over 13 years (Piper and Bindon, 1990). The animals were approximately 2.5 years of age, born and reared in the same environment. Heifers of each genotype were treated i.m. with either placebo or prototype inhibin vaccine; primary and booster vaccinations were given 28 days apart and the booster was administered on day 2 of a synchronized ovarian cycle. The following oestrus was synchronized to occur 20 days after the booster vaccination. Ovulation rate was assessed 11-12 days after oestrus by mid-ventral laparoscopic examination of the ovaries. Although independence tests of the ovulation rate data in Table $3\left(\chi^{2}\right.$ analysis, using proportions of heifers showing ovulation rates greater than I as the response variable) show that selection herd females were more responsive to the vaccine, subsequent analysis of deviance of this response variable indicated significant genotype $(P<0.05)$ and vaccine $(P<0.001)$ effects with a trend $(P=0.07)$ towards an interaction. The results suggest genetic differences in the sensitivity of animals to the vaccine. This result would be expected on the basis of the assumption that selection for twinning produces cattle that are closer to the physiological threshold for two ovulations.

\section{Ovarian overstimulation after first booster vaccination}

Although the day of cycle studies established that booster vaccination should be applied early in the ovarian cycle, it was evident (after the larger field trials using day 2 booster administration) that about 
$50 \%$ of responding animals had ovulation rates $\geq 4$. This problem was addressed in three experiments that examined the effects of varying the immunogen dosage in the vaccine to influence the immune and subsequent ovulatory response patterns to achieve a lower proportion of overstimulated cows (ovulation rate $>3$ ).

The first study, at Hamilton, involved mixed groups of Friesian $\times$ Hereford heifers and cows treated with vaccines containing $0,62.5,125,250$ or $500 \mu \mathrm{g}$ fusion protein antigen, with 28 -day booster vaccination on day 2 of a synchronized ovarian cycle and mated with bulls at the following oestrus. Analyses of the data showed significant differences between treated and control animals, but no effect of dose rate for measures of inhibin binding, mean ovulation rate and ovulation rate distribution or proportions of pregnant animals with live multiple fetuses at day 60 of pregnancy. The analyses also showed that there were no differences between the responses observed after the second inhibin vaccination in cows of different physiological state (that is heifers, early-and late-lactating, and dry cows).

The other two studies were designed to determine the minimum effective dose of immunogen and to examine whether supplementary progesterone could modify the immune or subsequent ovulatory responses. In the first experiment, 125 Angus $\times$ Hereford cows rearing none, one or two calves were randomly allocated among treatments of $0,3.9,7.8,15.6,31.2,62.5$ and $500 \mu \mathrm{g}$ of immunogen per vaccination. Half of the cows in each treatment were provided with supplementary progesterone $(1.9 \mathrm{~g}$ progesterone in inert silicone elastomer: CIDR.B intravaginal devices, Carter Holt Harvey Plastic Products, Hamilton) for either 18 days (two devices in succession), or 9 days (one device), corresponding to days $2-20$, or days $11-20$ of the synchronized cycle following booster vaccination. Cows were injected with $500 \mu \mathrm{g}$ cloprostenol 1 day before CIDR removal and artificially inseminated at oestrus.

In the second dose-response experiment, 79 Angus $\times$ Hereford cows were randomly allocated among four groups receiving $0,7.8,31.2$ and $62.5 \mu \mathrm{g}$ of recombinant inhibin- $\alpha .3$ immunogen. All of the control (placebo-treated) cows and half of the inhibin-vaccinated cows were synchronized to receive their second vaccination on day 2 of a synchronized cycle as above and received no further exogenous progesterone. The remaining inhibin-vaccinated cows were not synchronized before booster injection, but were given progesterone treatment for 18 days after booster immunization as above. The cows in this experiment were mated by natural service to bulls introduced 14 days after booster vaccination.

The data for each experiment were analysed both separately and together (least-squares mixed model ANOVA; Harvey, 1990). The models included effects of immunogen dosage and progesterone treatment(s) as well as post-calving interval and numbers of calves reared. The effect of immunogen dosage on ovulation rate was highly significant $(P<0,001)$ within each experiment and in the combined analyses. Significant linear $(P<0.05)$ and quadratic $(P<0.005)$ components described the relationship between immunogen dosage and ovulation response. Doses as low as $7.8 \mu \mathrm{g}$ could induce multiple ovulation and a plateau in response occurred after the $31.2 \mu \mathrm{g}$ immunogen dose in these cows (Fig. 1). There was no significant effect of progesterone treatment on ovulation rate in either experiment. Nor was there any significant effect on ovulation rate due to post-calving interval or rearing status, supporting the results of the Hamilton study above.

These experiments confirmed the extreme potency of the immunogen (recombinant ovine inhibin- $\alpha .3$ with Montanide:Marcol) and contrast markedly with the results obtained when appropriately conjugated inhibin- $\alpha$ peptides were used in more complex vaccines (Glencross et al., 1992, 1994; Morris et al., 1993; Scanlon et al, 1993). Early evaluations of the prototype (recombinant) vaccine showed that the initial ovulatory response in inhibin-immunized cattle depended on the timing of the booster vaccination within the preceding ovarian cycle. We inferred from this that sufficient time should elapse after immunization for the ensuing immune and physiological perturbations (altered FSH secretion and patterns of follicular growth and development) to occur and bring about the increase in ovulation rate.

Control of the highly variable ovulation rate response (i.e. overstimulation) after inhibin immunization with the recombinant antigen has not yet been achieved, either by changing the dose of the antigen in the vaccine or by giving supplementary progesterone. Further studies are required to address this aspect of the ovulatory response before commercial release of a reliable vaccine for twinning can be considered. 


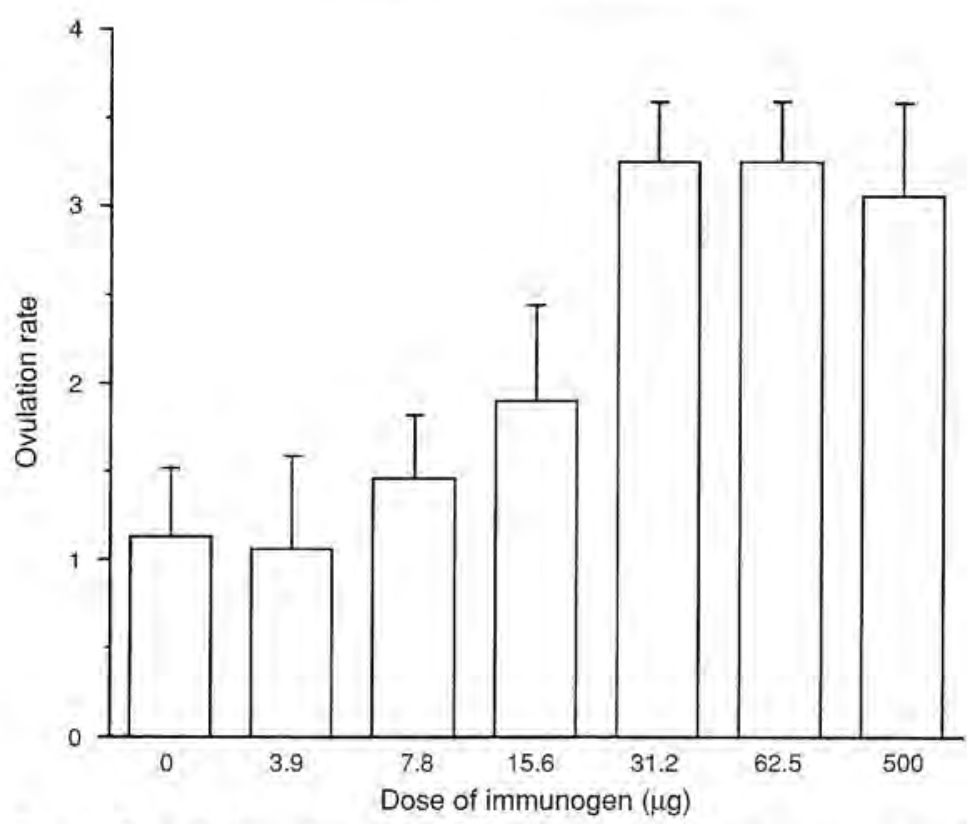

Fig. 1. Effect of dose of recombinant ovine inhibin- $\alpha .3$ antigen ( $\mu \mathrm{g}$ in $2 \mathrm{ml}$ vaccine, with Montanide:Marcol adjuvant) on ovulation rate (expressed as least-squares mean \pm SEM from least-squares mean ANOVA) in parous cows. Ovulation rates were significantly greater $(P<0.05-<0.001)$ in cows immunized with $\geq 15,6 \mu \mathrm{g}$ than in those treated with 0 or $3.9 \mu \mathrm{g}$. The response with 31.2 or 62.5 or $500 \mu \mathrm{g}$ was greater $(P<0.05)$ than that with $15.6 \mu \mathrm{g}$.

\section{Mode of Action of Inhibin Immunization}

According to our hypothesis, immunoneutralization of inhibin should promote a preferential increase in peripheral FSH concentrations and thereby result in alterations in folliculogenesis and increased ovulation rate. With appropriate sampling protocols, studies in sheep clearly show such relationships in ewes immunized (either actively or passively) with a range of inhibin antigens (O'Shea et al., 1989; Mann ef al., 1990, 1993; Wrathall et al, 1990; Wheaton et al., 1992). In addition, significant correlations have been shown between plasma inhibin binding, increased plasma FSH concentrations and subsequent ovulation rate increases in ewes (O'Shea et al., 1989, 1994).

\section{Plasma inhibin binding, gonadotrophin profiles, ovarian follicular dynamics and ovulation rate in cattle}

Investigations in heifers. In the study with heifers using different dose rates of recombinant ovine inhibin- $\alpha .3$ antigen in Montanide:Marcol adjuvant, primary immunization was followed by two booster vaccinations at 4 and II weeks, respectively. Oestrus was synchronized after each booster with two injections of synthetic PG (500 $\mu \mathrm{g}$ cloprostenol, i.m.) 10 days apart, the first being administered at the same time as each booster vaccination.

Ovulation rates for the synchronized oestrus (about 2 weeks) and the following natural oestrus (about 5 weeks) after each booster vaccination were monitored by mid-ventral laparoscopy $8-9$ days after oestrus detection. Response parameters were analysed with repeated measures (split-plot), or other appropriate models, using least-squares ANOVA procedures (Harvey, 1990), to determine treatment effects and linear correlations.

Highly significant plasma binding of iodinated native bovine inhibin $(P<0.001)$ was found in samples collected from inhibin-immunized heifers. Overall, inhibin binding in heifers treated with $125 \mu \mathrm{g}$ recombinant fusion protein $(13.8 \%)$ was lower $(P<0.05)$ than that measured in heifers treated with 
ovulation rate $>1$ were higher than those of treated heifers with ovulation rate of 1 only on days 2 and 3 before PG injection $(P<0.001$ and 0.02 ), at which time the FSH concentrations in non-responders were the same as those of controls. FSH concentrations in responding animals were higher than in controls $(P<0.001-<0.05)$ on all but the 2 days after PG injection. No differences were shown for overall $\mathrm{LH}$ concentrations among the various ovulation rate categories, but there were highly significant effects of time and time $\times$ response category interactions (both $P<0,001$ ) for mean daily LH concentrations. These effects were associated with differences among the ovulation rate response groups in the patterns of mean daily LH concentrations in the samples collected at days 2-4 after PG injection (data not shown).

These observations showed that to achieve an increased ovulation rate in inhibin immunized heifers, plasma FSH concentrations must be maintained for an extended period through the luteal phase before PG injection and in the following follicular phase of the cycle. This conclusion is supported by the demonstration by Wood et al. (1993) of regression of the preovulatory wave of follicles and delayed ovulation associated with suppression of plasma FSH, when inhibin-immunized heifers were treated with steroid-free bovine follicular fluid $(5 \mathrm{ml}$ every $4 \mathrm{~h}$ for $60 \mathrm{~h})$ commencing $8 \mathrm{~h}$ before PG induced luteolysis. Owing to limited observations of timing of onset of oestrus (at 06:00, 12:00 and 18:00 heach day), which showed no significant effects of inhibin immunization or response category, and blood sampling once a day, it is possible only to speculate about the significance of the LH results. Further detailed study of the patterns of LH secretion is required to establish the role of LH in the final stages of preovulatory follicular differentiation, which ultimately defines ovulation rate in cattle (for reviews see Ireland, 1987; Findlay; 1994; Fortune, 1994).

Investigations in parous cows. The effect of inhibin vaccination on ovarian follicular dynamics and ovulation rate was studied by observing follicles in cows that received their booster immunization at different stages (early, mid-and late) of a CIDR- and PG-synchronized oestrous cycle. Ultrasound observations of the ovaries were made every 2 days for 28 days following the boost. At each observation, the numbers of follicles in three size classes (small: $<5 \mathrm{~mm}$; medium: $5 \mathrm{~mm}$ to $<8 \mathrm{~mm}$, and large: $\geq 8 \mathrm{~mm}$ ) were recorded: follicle maps were not made. The follicle data for the 9-11 days preceding and the day after ovulation were analysed as described above for FSH profiles in heifers.

The results from this study showed that inhibin immunization had significant effects on ovulation rate and follicle populations (Fig. 4). When compared with control cows, more large follicles (169\% overall increase, $2.92 \pm 0.40$ in treated, $1.09 \pm 0.56$ in controls, $P=0.013$ ) and fewer small follicles $(2.43 \pm 0.37$ in treated, $3.96 \pm 0.52$ in controls, $P=0.023)$ were found at each observation in the ovaries of inhibin-immunized cows during the period of study. There was no treatment effect on numbers of medium follicles but a significant time effect $(P<0.01)$ reflected increased numbers of medium follicles on the day after ovulation for both control and inhibin-immunized cows. Inhibin immunization increased ovulation rate $(3.06 \pm 0.61, n=16$, compared with controls, $1.0, n=10$, $P<0.05$ ). Ovulation rate was correlated with the numbers of large follicles present on most days $(r=0.46-0.76, P<0.05-<0.001)$, particularly on the day before ovulation $(r=0.90, P<0.001)$, but with plasma inhibin binding only at 9 days before ovulation $(r=0.65, P<0.001)$, i.e, about the time of emergence of the preovulatory wave.

When cows were classified on the basis of treatment and ovulation response, plasma inhibin binding in the inhibin-immune cows that responded with increased ovulation rate was higher than that in non-responding inhibin-immunized cows $(59.8 \pm 1.4 \%$ versus $38.0 \pm 2.8 \%, P<0.01$, data not shown). Overall, responding cows had more large $(\geq 8 \mathrm{~mm})$ follicles and fewer small follicles $(<5 \mathrm{~mm})$ than did either non-responding or control animals $(P<0.001$ for all comparisons). Within-time comparisons showed that this effect was significant for large follicles at $1-9$ days before ovulation (Fig. 5a) but for small follicles the difference for both comparisons was significant only at 7 and 9 days before ovulation (Fig. 5b).

These findings with regard to increased numbers of large follicles during the preovulatory wave of follicular development in inhibin-immune cows are in agreement with the earlier reported studies in heifers immunized against synthetic fragment $\alpha_{1-29}$ of bovine inhibin- $\alpha$ subunit (Glencross et al., 1992, 1994; Wood et al., 1993). However, in the study reported here, no effect of inhibin vaccination was 


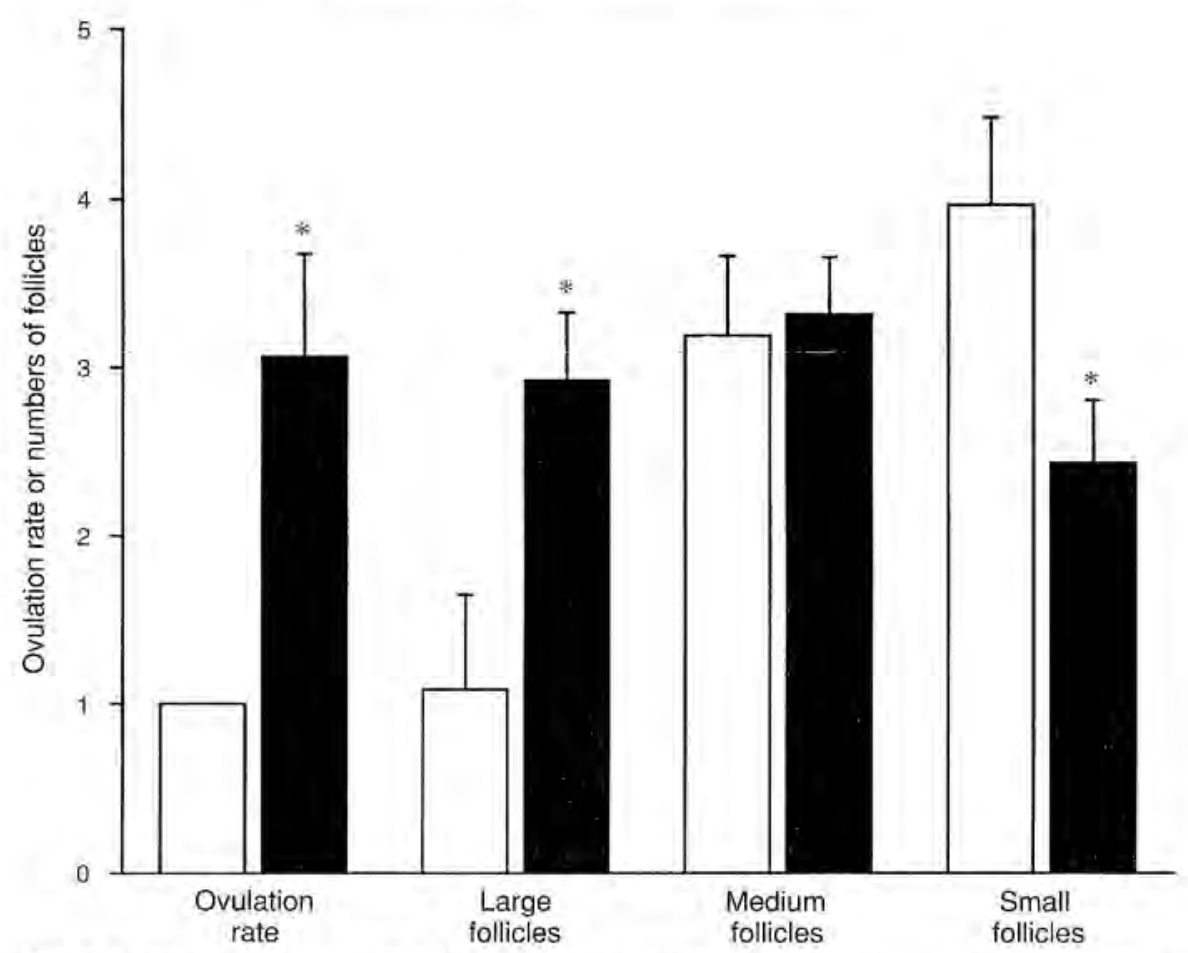

Fig. 4. Mean ( \pm SEM) ovulation rates and numbers (least-square means \pm SEM from least-squares mean ANOVA) of large ( $\geq 8 \mathrm{~mm})$, medium $(5-<8 \mathrm{~mm})$ and small $(<5 \mathrm{~mm}$ ) diameter follicles observed by ovarian ultrasonography every other day from II days before until the day after ovulation in eight control $(\square)$ and 15 inhibin-immunized ( $\mathbf{a}$ ) cows. $* P<0.05$ compared with controls.

shown on numbers of medium follicles in the preovulatory period, an effect which was evident in the studies with heifers of Glencross et al. (1992) and Wood et al. (1993). This discrepancy may be due to differences in the definition of follicle size categories.

The present studies are the first to show a coincidental reduction in the size of the small follicle population during the preovulatory wave of follicular development in the ovaries of inhibin-immunized cattle. The study further demonstrates that these divergent effects on the populations of large and small follicles are confined to immunized animals that have higher plasma inhibin binding and increased ovulation rates. This inverse relationship may reflect changes in the numbers of small follicles recruited into the final phases of growth and differentiation associated with folliculogenesis and ovulation (Ireland, 1987; Findlay, 1994; Fortume, 1994), due possibly to increased peripheral FSH concentrations as indicated by our earlier studies with heifers.

\section{Conclusions}

The above findings with regard to alterations in plasma inhibin binding, plasma FSH concentrations, numbers of ovarian follicles and growth patterns and subsequent ovulation rate in inhibin-immunized cattle support the general hypothesis that enhanced ovulation rate in inhibin-immunized cattle is due principally to the removal of endogenous feedback inhibition exerted by inhibin on pituitary FSH secretion. The resultant sustained increase in peripheral FSH concentration stimulates the recruitment and development of greater numbers of large growing follicles in the preovulatory follicular wave, some of which may ovulate after the preovulatory surge of $\mathrm{LH}$, if co-dominance is established and maintained. 

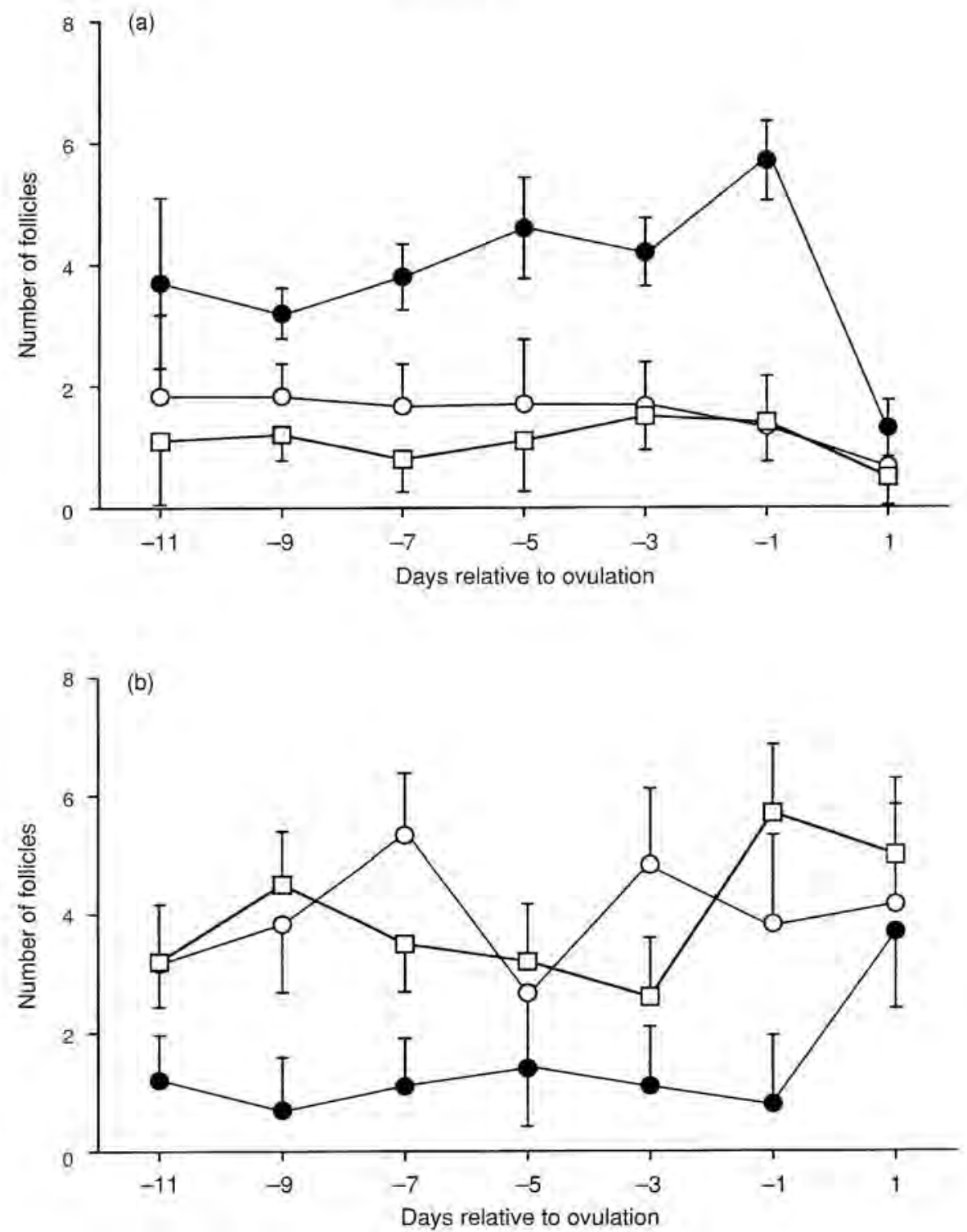

Fig. 5. Comparison of numbers (least-square means \pm sEM from least-squares mean ANOVA) of (a) large follicles $(\geq 8 \mathrm{~mm})$ diameter and (b) small follicles $(<5 \mathrm{~mm})$ in control $(\square)$, non-responder (ovulation rate of $1_{i} \bigcirc$ ), and responder (ovilation rate $>1_{i}$ ) inhibinimmunized cows. The data for each group are based on observations from ten (in eight control cows), eight (in seven non-responder cows) and 12 (in eight responder cows) pre-ovulatory/ post-ovulatory intervals (i.e. during the 9-11 days before and the day after ovulation). For both (a) and (b) responder cows differ significantly overall from non-responder and control cows $(P<0.001$ for all contrasts from least-squares mean ANOVA). There were no significant differences between non-responders and controls in (a) or (b). Within-time contrasts show responder cows have more large follicles than did the other two groups on days -1 to $-9(P<0.05-<0.001)$, and fewer small follicles than the control cows on days -1 $(P<0.01),-7(P<0.05)$ and $-9(P<0.01)$, and fewer small follicles than non-responder cows on days $-3(P<0.05),-7(P<0.01)$ and $-9(P<0.05)$. 
The current studies add further support to this hypothesis by demonstrating significant correlations between the various parameters of response (i.e. plasma inhibin binding, peripheral FSH concentrations, numbers of developing large follicles in the preovulatory wave and resulting ovulation rate) measured in either PG-induced or natural ovarian cycles following inhibin immunization. These results support the concept that FSH plays a critical role in various processes of folliculogenesis (recruitment, dominance and selection of the ovulatory follicle(s)) associated with the growth and differentiation of the cohort of follicles that comprise the preovulatory wave. The results reported here also indicate that intensive investigation of the patterns of $\mathrm{LH}$ secretion in the period after luteolysis should be undertaken to define the physiological role of LH in the final stages of selection and growth of the ovulatory follicle(s) in cattle.

The authors acknowledge the skilled technical assistance of R. Nethery, G. Uphill, B. Makings, C. Andrews, A. Clark, I. Mcleod, and D. Russell. They thank I. Davies for statistical advice. The research was supported by grants from the Meat Research Corporation.

\section{References}

Al-Obaidi SAR, Bindon BM, Findlay IK, Hillard MA and O'Shea T (1987) Plasma follicle stimulating hormone in Merino ewes immunized with an inhibin-enriched fraction from bovine follicular fluid Animal Reproduction Scierice 14 39-51

Bindon BM, O'Shea I, Miyamoto K, Hillard MA, Piper LR, Nethery RD and Uphill G (1988) Superovulation in pubertal heifers immunized against ovine inhibin purified by monoclonal antibody affinity chromatography Proceedings of the Australian Society for Reproductive Biology 20 Abstract 28

Bindon BM, Anderson ST, Cummins LJ, Findlay JK, Hillatd MA, O'Shea T, Paull D, Tsonis CG and Wilkins JF (1994) Manipulation of reproduction of sheep and cattle by vaccination against inhibin-related pepfides. In Vaccines in Agriculture: Impunological Applications to Animal Heallh and Production pp 85-96 Eds PR Wood, P Willadsen, JE Vercoe, RM Hoskinson and D Demeyer. CSIRO Publications, Melbourne

Boland MP, Nancarrow CD, Hoskinson RM, Murray JD, Scaramuzzi RJ, Radford HM, Avenell JA and Bindon BM (1985) Superovulatory response in cows following immurization against testosterone and treatment with bovine follicular fluid and PMSG Theriogenology 23 Abstract 180

Croker KP, Cox RI, Johns MA, Johnson TJ, Roberts D, Salerian M and Sunderman F (1988) Potential for Fecundin to influence the performance of Merino ewes in Western Australia Australian Journal of Biological Science 41 47-55

Cummins LJ, O'Shea T and Bindon BM (1986) Increased ovulation rates in cattle vaccinated with a partially purified fraction of ovine follicular fluid Proceedings of the Australian Society for Reproductive Biology 18 Abstract 39

D'Occhio MJ (1993) Immunological suppression of reproductive function in male and fernale mammals Animal Reproduction Science 33 345-372

Findlay JK (1994) Peripheral and local regulators of fol liculogenesis Reproduclion Fertility and Development 6 $127-139$

Forage RG, Brown RW, Oliver KJ, Attache BT, Devine $\mathrm{PL}_{\text {, }}$ Hudson GC, Goss WH, Bertram KC, Tolstoshev P, Robertson DM, Doughton B, Burger HG and Findlay JK (1987) Immunisation against an inhibin subunit produced by recombinant DNA techniques results in increased ovu lation rate in sheep Joumal of Endocrinology 114 RI-R4
Fortune JE (1994) Ovarian follicular growth and development in mammals Biology of Reproduction $\mathbf{5 0}$ 225-232

Glencross RG, Bleach ECL, McLeod BJ, Beard AJ and Knight PG (1992) Effects of active immurization of heifers against intribin on plasma FSH concentrations, ovarian follicular development arid ovulation rate Journal of Endocrinology $13411-18$

Glencross. RG, Bleach ECL, Wood SC and Knight PG (1994) Aclive immunization of heifers against inhibin: effects on plasma concentrations of gonadotrophins, steroids and ovarian follicular dynamics during prostaglandinsynchronized cycles Journal of Reproduction and Fertility 100 $599-605$

Harvey WR (1990) Users guide for LSMLMW, PC-2 Version, Ohio State University Press, Columbus

Henderson KM, Franchimont P, Lecomte-Yerna MJ, Hudson N and Ball K (1984) Increase in ovulation rate after active immunization of sheep with inhibin partially purified from bovine follicular fluid Journal of Endocrinology $\mathbf{1 0 2}$ 305-309

Hillard MA, Bindon BM, King B, O'Shea T, Andrews CA and Hinch GN (1990) Superovulation of cows immunized against native ovine inhibin Proceedings of the Australian Sociely for Reproductive Biology 22 Abstract 134

Hillard MA, Bindon BM, Wilkins JF, Cummins L.J, Tsonis CG and Findlay JK (1994) Inhibin vaccines for increased ovulation rate and fecundity in cattle Proceedings of the Australian Society of Animal Production $2027-28$

Hoskinson RM, Scaramuzzi RJ, Campbell BK, Downing JA, Welch RJ and Harrison BE (1986) Effects of antibodies to steroid hormones on reproductive events of sheep and cattle. In Immunological Approaches to Contraception and Promotion of Fertility pp 351-366 Ed. GP Talawar. Plenum Press, New York

Hoskinson RM, Rigby RDG, Mattner PE, Huynh VL, D'Occhio M, Neish A, Trigg TE, Moss BA, Lindsey MJ, Coleman GD and Schwarzkoff CL (1990) Vaxstrate ${ }^{\text {10 }}$ An anti-reproductive vaccine for cattle Australian Journal of Biolechnology 4 $166-176$

Ireland J] (1987) Control of follicular growth and development Journal of Reproduction and Fertility, Supplement 34 39-54

McCullagh P and Nelder JA (1989) Generalised Linear Miodels pp 21-47 Chapman and Hall, London 
McNatty KP, Henderson KM, Fleming JS, Clarke IJ, Bindon BM, Piper LR, O'Shea T, Hillard MA and Findlay JK (199I) The physiology of the Booroola ewe. In Major Genes for Reproduction in Sheep pp 105-124 Eds JM Elsen, L Bodin and $\mathrm{J}$ Thimonier. INRA, Paris

Mann GE, Campbell BK, McNeilly AS and Baird DT (1990) The effects of passively immunizing ewes against inhibin and oestradiol during the follicular phase of the oestrous cycle Journal of Endocrinology 125 417-424

Mann GE, Campbell BK, McNeilly AS and Baird DT (1993) Follicular development and ovarian homone secretion following passive immunization of ewes against inhibin or oestradiol Journal of Endocrinology 136 225-233

Morris DG, McDermott MG, Diskin MG, Morrison CA, Swift PJ and Sreenan JM (1993) Effects of immunization against synthetic peptide sequences of bovine inhibin $\alpha$-suburit on ovulation rate and twin-calving rate in heifers Joumal of Reproduction and Fertility 97 255-261

O'Shea T, Cummins LJ, Bindon BM and Findlay JK (1982) Increased ovulation rate in ewes vaccinated with an inhibin-enriched fraction from bovine follicular fluid Proceedings of the Australian Sociefy for Reproductive Biology 14 Abstract 85

O'Shea T, AI-Obaidi SAR, Bindon BM, Cummins LJ, Findlay IK and Hillard MA (1984) Increased ovulation rate in Merino ewes and advancement of puberty in Merino lambs immunized with a preparation enriched in inhibin In Reproduction of Sheep. pp 335-337 Eds DR Lindsay and DT Pearce. Australian Academy of Science, Canberra

O'Shea T, Bindon BM, Hillard MA, Piper LR, Findlay JK and Miyamoto K (1989) Increase in ovulation rate in Merino ewes after active immunization with inhibin preparations obtained by immunoaffinity chromatography Reproduction Fertility and Development 1 347-355

O'Shea T, Hillard MA, Anderson, ST, Bindon BM, Findlay JK, Tsonis CG and Wilkins JF (1994) Inhibin immunization for increasing ovulation rate and superovulation Theriogenology 41 3-17

Philipon P and Driancourt MA (1987) Potential of active immunization against androstenedione to improve fecundity in sheep Animal Reproduction Science 15 I0I-112

Piper LR and Bindon BM (1990) Genetic and non-genetic approaches to increasing prolificacy in beef cattle Australian Association of Animal Breeding and Genetics 8 381-388

Price CA, Morris BA and Webb R (1987a) Reproductive and endocrine effects of active immunization against a testosterone conjugate in the heifer Journal of Reproduction and Fertility 81 149-160

Price CA, Morris BA, O'Shea T and Webb R (1987b) Active immunization of cattle against partly purified follicular fluid from sheep Journal of Reproduction and Fertility 81 161-168
Rhind SM, Schemm RS and Schanbacher BD (1993) Follicle populations, ovulation rates and profiles of gonadotropins, inhibin and insulin-like growth factor-1 of heifers actively immunized against androstenedione and inhibin, separately or in combination Animal Production 57 55-63

Scanlon AR, Sunderland SJ, Martin TL, Goulding D, O'Callaghan D, Williams DH, Headon DR, Boland MP, Ireland JI and Roche JF (1993) Active immurization of heifers against a synthetic fragment of bovine inhibin Journal of Reproduction and Fertility 97 213-222

Scaramuzzi RJ and Hoskinson RM (1984) Active immunization against steroid hormones for increasing fecundity. In Immu. nological Aspecis of Reproduction in Mammals pp 445-474 Ed. DB Crighton, Butterworths, London

Scaramuzzi RJ, Davidson WG and Van Look PFA (1977) Increasing ovulation rate in sheep by active immunization against an ovarian steroid, androstenedione Nature 269 $817-818$

Smith JF (1985) Steroid immunization of ewes to increase Jambing Proceedings of the Neto Zealand Society of Animal Production 45 171-198

Sreenan JM (1984) Steroid immunization in cows: potential for increasing ovulation and twinning rates Toth International Congress on Animal Reproduction and Artificial Insemination (Urbana-Champaign) $4 \quad 22-27$

Walton JS (1985) Effect of active immunization against androstenedione on ovarian function in dairy cows and prepubertal gilts Animal Reproduction Science 8 349-364

Wheaton JE, Carlson KM and Kusina NT (1992) Active and passive immunoneutralization of inhibin increases folliclestimulating hormone levels and ovulation rate in ewes Biology of Reproduction 47 361-367

Wilkins JF, Hennessy DW, Cummins LJ and Hillard MA (1994) Embryo loss in multiple bearing cows Proceeding of the Australian Society of Animal Production 20 29-30

Wise TH and Schanbacher BD (1983) Reproductive effects of immunizing heifers against androstenedione and oestradiol17ß Joumal of Reproduction and Fertility $69005-612$

Wood SC, Glencross RG, Bleach ECL. Lovell R, Beard AJ and Knight PG (1993) The ability of steroid-free bovine follicular fluid to suppress FSH secretion and delay ovulation persists in heifers actively immunized against inhibin Journal of Endocrinology 136 137-148

Wrathall JHM, McLeod BJ. Glencross RG, Beard AJ and Knight PG (1990) Inhibin immunoneutralization by antibodies raised against synthetic peptide sequences of inhibin $\alpha$-subunit: effects on gonadotrophin concentrations and ovulation rate in sheep Journal of Endocrinology 124 $167-176$ 